\title{
Proposal for an Abridged Nitrogen Turnover Cycle in Certain Marine Planktonic Systems Involving Hypoxanthine-Guanine Excretion by Ciliates and Their Reutilization by Phytoplankton
}

\author{
N. J. Antia ${ }^{1}$, B. R. Berland ${ }^{2}$ and D. J. Bonin ${ }^{2}$ \\ ${ }^{1}$ West Vancouver Laboratory, Fisheries Management, Canadian Department of Fisheries \& Oceans, 4160 Marine Drive, West \\ Vancouver, B. C., V7V IN6 Canada \\ ${ }^{2}$ Station Marine d'Endoume, F-13007 Marseille, France
}

\begin{abstract}
At the concentration of $0.125 \mathrm{mM}$, the purine hypoxanthine is shown to be a good and energy-efficient nitrogen source for phototrophic growth of at least $60 \%$ of 26 tested species of marine microalgae from 10 taxonomic classes. At 10 -fold higher concentration, this purine generally augmented growth of the species showing fair-to-good growth on the low concentration, and this growth increase was dramatic for most flagellates. However, the higher concentration level caused weak or no growth improvemen: of the species showing poor purine utilization at the lower level. There was no indication of hypoxanthine concentration toxicity, and the maximal growth yields achieved by the best purine utilizers indicated assimilation of all $4 \mathrm{~N}$ atoms per molecule of hypoxanthine. These results are combined with the recently reported excretion of hypoxanthineguanine by marine ciliates to suggest a short-circuited $\mathrm{N}$-turnover cycle in certain planktonic associations whereby the excreted purines may be directly reutilized by a large proportion of marine phytoplankton.
\end{abstract}

\section{INTRODUCTION}

The utilization of various purines as nitrogen source for phototrophic growth of marine microalgae is now well established for species from numerous taxa (Droop, 1955, 1961; Guillard, 1963; Van Baalen and Marler, 1963; Antia and Chorney, 1968; Gooday, 1970; Turner, 1970; Kapp et al., 1975; Mahoney and McLaughlin, 1977). Whereas uric acid was the most widely tested purine in these investigations, Antia and Landymore (1974) cautioned that the chemical instability of this purine and its close relative, xanthine, in seawater could give false results if the algae were utilizing one or more decomposition products instead of the intact purines. This would not be the case with the other purines hypoxanthine and guanine, whose stability in algal culture media was established.

Using this rationale, Antia et al. (1975) surveyed growth on hypoxanthine of 26 species of marine microalgae from 10 taxonomic classes and observed purine utilization by 18 species from all, but 2 , of the algal classes tested. Some of these species required considerably long periods of adaptation, but in most cases the ultimate (maximal) growth density was nearly equal to that supported by equivalent nitrogen from nitrate or ammonium. Since hypoxanthine contains $4 \mathrm{~N}$ atoms per molecule (Fig. 1), this observation indicated that such algae were efficiently utilizing all the nitrogen from hypoxanthine supplied at a concentration $(0.125 \mathrm{mM})$ equal to a quarter of that of nitrate or ammonium $(0.5 \mathrm{mM})$. This purine concentration could be too low for successful uptake by those algae showing poor or no utilization. It was therefore considered of interest to re-examine the phototrophic growth of

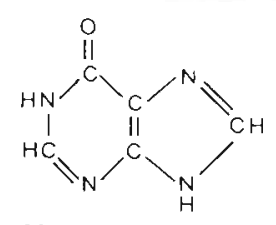

Hypoxanthine<smiles>Nc1nc2[nH]cnc2c(=O)[nH]1</smiles>

Guanine
Fig. 1. Molecular structures of hypoxanthine and guanine Note the number of $\mathrm{N}$ atoms in each structure, and consider the elaborate metabolic machinery required by an alga to degrade the purine ring-skeleton and assimilate the liberated $\mathrm{N}$ atoms for protein biosynthesis during growth 
most of the previously investigated species on 10 -fold higher concentration (1.25 mM) of hypoxanthine, using the same algal strains and methodology as previously described (Antia et al., 1975).

\section{EXPERIMENTAL}

Summarized in Table 1, the combined results of the present and past surveys show that the species unable to utilize hypoxanthine at low concentration are also generally unable to utilize it at the higher concentration. Two species (Emiliania huxleyi, Monallantus salina), with poor growth (ca. 10-20\% of the nitrategrown control) on the low purine concentration, showed significant but relatively weak (ca. 20-40\%) growth improvement at the higher concentration (Fig. 2). Hypoxanthine concentration was generally not inhibitory, excepting the doubtful case of Fragilaria pinnata whose growth was slight (and unreliable) at low concentration and totally suppressed at the higher concentration (Fig. 2). Most of the species showing

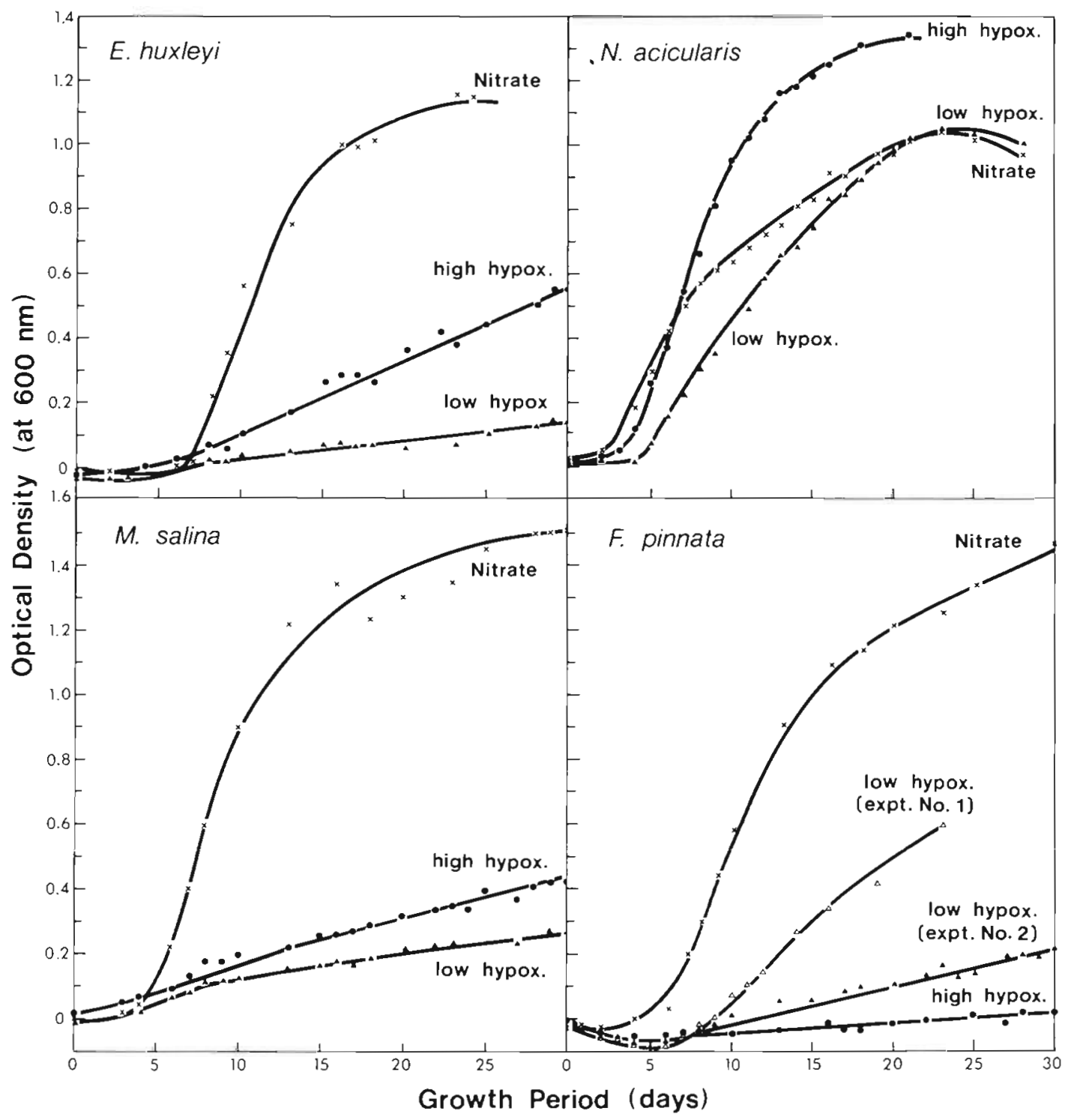

Fig. 2. Growth curves of Emiliania huxleyi, Monallantus salina, Fragilaria pinnata, and the benthic diatom Nitzschia acicularis on low $(0.125 \mathrm{mM})$ and high $(1.25 \mathrm{mM})$ concentrations of hypoxanthine or nitrate $(0.5 \mathrm{mM})$, each compound serving as sole $\mathrm{N}$ source for growth. In each case, growth was initiated by inoculum taken from nitrate (or ammonium) habituated stock cultures. Note that the growth of $F$. pinnata on the low purine concentration was unreliable in varying widely between two separate 
Table 1. Index of tested algal species ${ }^{\mathrm{a}}$ found to utilize hypoxanthine as sole $\mathrm{N}$-source for phototrophic growth under continuous illumination (intensity ca. $2 \mathrm{klx}$ ) at $18^{\circ} \mathrm{C}$. The tests were made on low $(0.125 \mathrm{mM}$ ) and high $(1.25 \mathrm{mM})$ concentrations of hypoxanthine

\begin{tabular}{|c|c|c|c|}
\hline \multirow[t]{2}{*}{ Algal class } & \multicolumn{3}{|c|}{ Species showing } \\
\hline & $\begin{array}{l}\text { Fair-to-good utilization on low conc., } \\
\text { and growth augmentation on high conc. }\end{array}$ & $\begin{array}{l}\text { Poor growth on low conc., } \\
\text { but significant improvement } \\
\text { on high conc. }\end{array}$ & $\begin{array}{l}\text { Slight or no growth on both } \\
\text { concs. }\end{array}$ \\
\hline Chlorophyceae & $\begin{array}{l}\text { Chlamydomonas palla }{ }^{b}, \text { Dunaliella } \\
\text { tertiolecta }\end{array}$ & - & - \\
\hline Prasinophyceae & $\begin{array}{l}\text { Prasinocladus marinus } s^{c, d}, \text { Tetraselmis } \\
\text { maculata }{ }^{b}, \text { Tetraselmis striata }\end{array}$ & - & - \\
\hline Eustigmatophyceae & - & Monallantus salina & Nannochloris oculata \\
\hline Prymnesiophyceae & Isochrysis galbanac,d, Pavlova lutheri ${ }^{b}$ & Emiliania huxleyi & - \\
\hline Xanthophyceae & Heterothrix sp. & - & - \\
\hline Bacillariophyceae & $\begin{array}{l}\text { Amphora hyalina }{ }^{b} \\
\text { Cylindrotheca closterium, Navicula } \\
\text { biskanteri }^{b}, \text { Nitzschia acicularis, } \\
\text { Phaeodactylum tricornutum }\end{array}$ & - & $\begin{array}{l}\text { Cyclotella cryptica, Fragilaria } \\
\text { pinnata }^{e}\end{array}$ \\
\hline Cryptophyceae & $\begin{array}{l}\text { Chroomonas salina, Hemiselmis } \\
\text { virescens } s^{b, c}\end{array}$ & - & Rhodomonas lens \\
\hline Dinophyceae & Amphidinium carteri & - & - \\
\hline Rhodophyceae & - & - & Porphyridium marinum \\
\hline Cyanophyceae & - & - & $\begin{array}{l}\text { Agmenellum quadruplicatum, } \\
\text { Anacystis marina, } \\
\text { Synechococcus } 7335\end{array}$ \\
\hline \multicolumn{4}{|c|}{$\begin{array}{l}{ }^{a} \text { Note that this list has been up-dated from that of the earlier survey (Antia et al., 1975) to take into account the more recent } \\
\text { taxonomic and/or nomenclatural revisions detailed by Berland et al. }(1976,1979) . \\
{ }^{b} \text { Not tested on high concentration. } \\
{ }^{c} \text { Required long adaptation. } \\
\text { d Little growth improvement at high concentration. } \\
\text { e Significant (but erratic) growth at low, and none at high concentration. }\end{array}$} \\
\hline
\end{tabular}

good growth at the low concentration level produced considerable gain in growth at the higher level (example of a benthic diatom shown in Fig. 2), and this increase was dramatic for a dinoflagellate, a cryptomonad, a chlorophycean and a prasinophycean flagellate (Fig. 3). The purine concentration appeared to have little influence on the adaptation lag of species requiring prolonged adaptation, as illustrated by the case of Tetraselmis striata (Fig. 3). None of the tested species showed any evidence of growth under total darkness, irrespective of hypoxanthine concentration.

The overall summation of these observations leaves no doubt that hypoxanthine is a good $\mathrm{N}$-source for growth, in light, of a large percentage (at least $60 \%$ in the present survey) of marine phytoplankters, irrespective of the magnitude of its concentration level. Since hypoxanthine is sparingly soluble in seawater (limit estimated at ca $5 \mathrm{mM}$ from the data of Pfleiderer, 1963) and therefore cannot reach high (possibly toxic) dissolved levels, we suggest that this purine is entirely beneficial, as a nitrogen-rich nutrient, to marine phytoplankton at concentrations ranging from microgram values to solubility saturation.

\section{DISCUSSION AND CONCLUSIONS}

Uptake-energy considerations suggest that, at low concentrations, hypoxanthine should be considerably superior as nutrient than nitrate, nitrite, or ammonium, since it contains 4-times as much nitrogen per molecule (Fig. 1) as the inorganic N-sources. Furthermore, its sparing solubility in seawater ensures that it can never reach toxic dissolved levels, unlike the toxic concentrations known for ammonium and nitrite (Antia and Chorney, 1968; Mahoney and McLaughlin, 1977). The same arguments apply, even more forcibly, to guanine as $\mathrm{N}$-source for phytoplankter growth, since this purine contains one more $\mathrm{N}$-atom per molecule than hypoxanthine (Fig. 1) and is estimated to be at least 100-times less soluble (Pfleiderer, 1963). Although we have not examined guanine in our surveys, other investigations have shown it to support generally good growth of a cryptomonad (Antia and Chorney, 1968), 2 prasinophycean (Gooday, 1970) and 6 chlorophycean flagellates (Droop, 1961). We are thus led to infer that both hypoxanthine and guanine are ecologically realistic $\mathrm{N}$-sources for phototrophic 


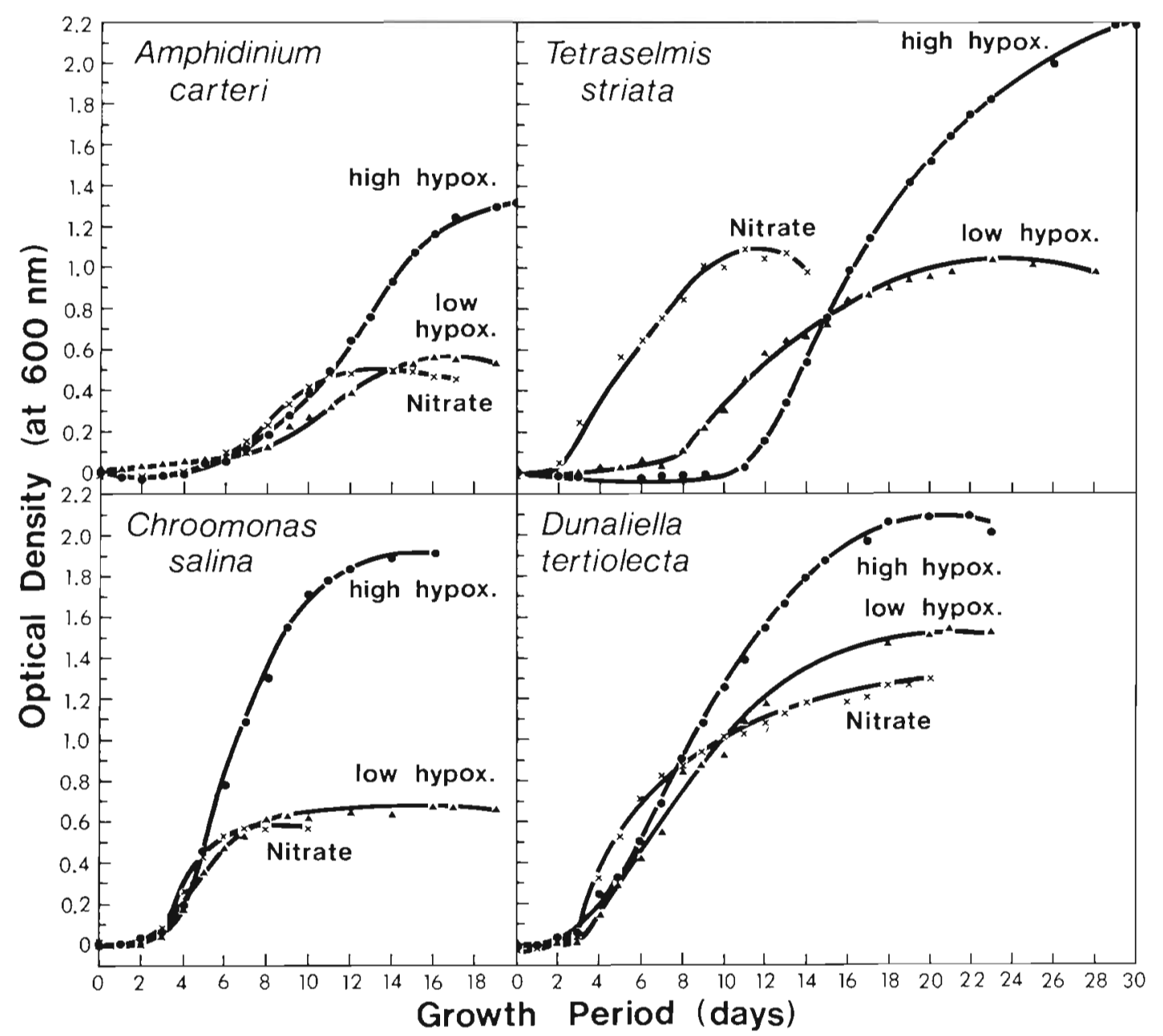

Fig. 3. Growth curves of four phytoflagellates (from 4 different classes of algae, see Table 1) on low (0.125 mM) and high (1.25 $\mathrm{mM}$ ) concentrations of hypoxanthine or nitrate $(0.5 \mathrm{mM})$, each compound serving as sole N-source. Nitrate-habituated stock cultures provided the inocula used to initiate each growth shown

growth of a large variety and proportion of marine phytoplankton. This appears to be particularly true of the flagellate members with respect to both the purines.

The question then arises about the source of these purines in the marine environment. This question was raised by Antia et al. (1975), who suspected that the principal sources of hypoxanthine remained unknown at that time. Since then, an important investigation on the excretory products of marine ciliates has unwittingly answered this question. Using axenic cultures of a small hymenostome ciliate, Soldo et al. (1978) isolated cytoplasmic crystalline bodies composed principally of hypoxanthine and guanine in the ratio $1: 4$, and these bodies were inferred from other evidence to be excretory in function. Since similar cytoplasmic inclusions have been observed in other marine ciliates, these investigators believe that hypoxanthine-guanine excretion may be a common metabolic feature of cili- ates. It thus appears that such purine excretion may form an important contribution to the total nitrogen pool available for phytoplankton growth in the case of 'blooms' where ciliates and microalgae co-exist.

There have been few studies made on ciliate associations with microalgae and these have shown cases of protozoan ingestion or feeding on algae from numerous taxa (Blackbourn et al., 1973; Hartwig and Parker, 1977; Radzikowski and Golembiewska, 1977; Repak et al., 1979). However, likely nutritional benefits to the algae deriving from ciliate excretions have been hitherto ignored, because such excretions were commonly assumed to be fecal-type organic and therefore consumed only by bacteria. Various modes of purine utilization by terrestrial bacteria and fungi have been summarized in a recent review (Vogels and Van der Drift, 1976), which points out that there is barely any published information on this subject with regard to the marine counterparts of these microorganisms. Until 
such information becomes available, it is not possible to judge the quantitative aspects of the consumption of ciliate-excreted purines by microalgae vis-à-vis bacteria and fungi in the marine environment. At any rate, our results indicate that ciliate-associated microalgae could be important purine consumers in the euphotic zone.

We believe that the classical cycle of nitrogen turnover in the aquatic environment has overemphasized (a) the role of bacteria in the exclusive consumption of dissolved organic matter, (b) the role of inorganic nitrogen compounds (nitrate, nitrite, ammonia) as the only N-sources for phototrophic growth of phytoplankton. Furthermore, this classical cycle presupposes that all organic- $\mathrm{N}$ in seawater must be processed through the long and energy-wasteful route of bacterial metabolism and ultimate decomposition to inorganic- $\mathrm{N}$ before it becomes available to phytoplankton. Our observations suggest that, at least in the case of ciliate-phytoplankton associations, this classical cycle needs revision involving a short-circuit so that the organic- $\mathrm{N}$ from ciliate purinoid excretion is utilized directly by phytoplankter growth without the mediation of bacteria. A recent report on the seasonal variations of dissolved inorganic and organic nitrogen concentration levels in the waters of the English Channel, during an 11-year study, also casts doubt on the classical N-turnover cycle and concludes that marine phytoplankters are directly using organic $\mathrm{N}$-compounds at certain seasons (Butler et al., 1979). Owing to lack of suitable methods for the routine analysis and identification of the wide variety of dissolved organic nitrogenous compounds that could occur in seawater, these investigators concentrated only on urea known to be excreted by copepods. However, it is not unlikely that ciliate-excreted purines might have periodically constituted a significant proportion of the dissolved organic-N pool. Two other studies have come to similar conclusions without awareness of the role of excreted purines; in these studies, intermittent pulses of microscale nutrient regeneration from zooplankter excretion were inferred to be responsible for maintaining maximal growth rates of phytoplankton under oceanic conditions of deficiency of the classical inorganic nutrients (Goldman et al., 1979; McCarthy and Goldman, 1979).

The long lag periods of adaptation to hypoxanthine shown by some microalgal species in our surveys (Table 1) should not raise serious objections to our above proposal of an abridged nitrogen cycle in the marine environment, because we have previously shown that after complete adaptation these species resume growth in fresh medium with little or no timelag (Antia et al., 1975). As these species were routinely maintained in culture collections on nitrate (or glycine, in the case of Hemiselmis virescens) as N-source for several years, it is not surprising that they would need considerable time to adjust their metabolic machinery on first exposure to the purine. But in the natural environment they are expected to encounter such exposures frequently.

Strictly speaking, the ciliate-excreted purinoid bodies should be considered metabolically equivalent to the zooplankter fecal pellets (see recent review by Turner and Ferrante, 1979), but their microscopic size (ca $5 \times 2 \mu \mathrm{m}$, according to Soldo et al., 1978) and solubility (see below) probably qualifies them in a category intermediate between excreted dissolved organic matter and the fecal pellets; this size qualification entails the ecological implication that they are probably too small for degradation from the bacterial surface adhesion commonly assumed for the fecal pellets. Soldo et al. (1978) report the ciliate purinoidexcretory bodies to be insoluble in water, but it is not clear whether they are talking of immediate solubility or whether the purines in the bodies are in a peculiar physical or chemical state. We have found crystalline hypoxanthine and, particularly, guanine to be very sparingly soluble in seawater, and, in order to obtain quicker dissolution, we have been obliged to apply heat. The ultraviolet absorption spectra of such solutions, reported by Antia and Landymore (1974), leave no doubt of the solubility of the individual purines in seawater. It is likely that temperature may have considerable effect on the rates of purine dissolution, in which case the ciliate-excreted bodies are expected to dissolve very slowly under natural temperature conditions. Such slow dissolution may persist for very long intervals of time, thereby providing a continuous low level of nitrogenous nutrient for phytoplankter growth. Antia (unpublished) has observed growth of Hemiselmis virescens in the presence of undissolved particles of guanine, implying continuous slow dissolution of the purine in the absence of phagotrophy (a mode of nutrition hitherto undemonstrated for $\mu$-flagellates). Until complete dissolution occurs, the ciliate-excreted bodies may become enmeshed in the pelagic macroscopic aggregates constituting marine snow (Alldredge, 1979) or sink to the bottom of the water column. In the former case, their gradual dissolution could provide continuous low-level nitrogenous nutrition to pelagic forms of phytoplankton (especially the phytoflagellates), while in the latter case they may perform the same function with respect to the benthic forms (cf. most diatoms in Table 1). In view of such possibilities of excreted-purine dispersal in marine systems, it is not unlikely that the long-term benefited microalgae may also include those not immediately associated with the purine-producing ciliates.

A diagram of our proposed abridged nitrogen cycle is shown in Figure 4, which considers the ciliates apart 


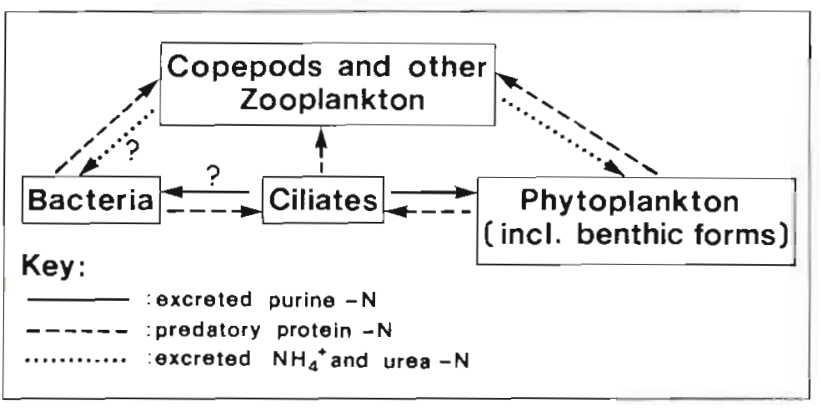

Fig. 4. Abridged N-turnover cycle in marine ecosystems, showing direct utilization, by phototrophs, of known excreted forms of dissolved $\mathrm{N}$-compounds, and phagotrophic ingestion of microbial proteinaceous- $\mathrm{N}$ by predators. The scheme does not negate the classical inorganic- $\mathbf{N}$ cycle, but purports to refine it by inserting 'short-circuits' necessitated by recent

findings on faunal nitrogenous excretions (see the text)

from other zooplankton and takes into account more recent information on the predation of bacteria by ciliates (Fenchel et al., 1977; Parker, 1978; Porter et al., 1979) and harpacticoid copepods (Brown and Sibert, 1977), as well as the predation of ciliates by crustacean zooplankters (Porter et al., 1979). In concluding our proposal, we urge oceanographers and marine ecologists to stop ignoring the role of dissolved organic- $\mathrm{N}$ in estimating photosynthetic primary production. The large pools of unidentified organic-N, reported seasonally for coastal waters (Butler et al., 1979) and saltmarsh estuarine areas (Valiela and Teal, 1979), need to be adequately analysed for components (such as amines, amino acids, purines, urea), and the planktonic turnover of these components needs to be quantified.

Acknowledgements. The technical assistance of Mlle. Denise Arlhac is gratefully acknowledged. Valuable exchange of information was facilitated by a NATO Travel Grant from the Special Programme Panel on Marine Sciences (Grant No. SRG 17).

\section{LITERATURE CITED}

Alldredge, A. L. (1979). The chemical composition of macroscopic aggregates in two neretic seas. Limnol. Oceanogr. 24: 855-866

Antia, N. J., Chorney, V. (1968). Nature of the nitrogen compounds supporting phototrophic growth of the marine cryptomonad Hemiselmis virescens. J. Protozool. 15: 198-201

Antia, N. J., Landymore, A. F. (1974). Physiological and ecological significance of the chemical instability of uric acid and related purines in seawater and marine algal culture medium. J. Fish. Res. Bd Can. 31: 1327-1335

Antia, N. J., Berland, B. R., Bonin, D. J., Maestrini, S. Y (1975). Comparative evaluation of certain organic and inorganic sources of nitrogen for phototrophic growth of marine microalgae. J. mar. biol. Ass. U. K. 55: 519-539

Berland, B. R., Bonin, D. J., Maestrini, S. Y., LizárragaPartida, M. L., Antia, N. J. (1976). The nitrogen concentra- tion requirement of D-glucosamine for supporting effective growth of marine microalgae. J. mar. biol. Ass. U. K. 56: 629-637

Berland, B. R., Bonin, D. J., Guérin-Ancey, O., Antia, N. J. (1979). Concentration requirement of glycine as nitrogensource for supporting effective growth of certain marine microplanktonic algae. Mar. Biol. 55: 83-92

Blackbourn, D. J., Taylor, F. J. R., Blackbourn, J. (1973). Foreign organelle retention by ciliates. J. Protozool. 20: 286-288

Brown, T. J., Sibert, J. R. (1977). Food of some benthic harpacticoid copepods. J. Fish. Res. Bd Can. 34: 1028-1031

Butler, E. I., Knox, S., Liddicoat, M. I. (1979). The relationship between inorganic and organic nutrients in seawater. $J$. mar. biol. Ass. U. K. 59: 239-250

Droop, M. R. (1955). Some new supralittoral Protista. J. mar. biol. Ass. U. K. 34: 233-245

Droop, M. R. (1961). Haematococcus pluvialis and its allies. III: Organic nutrition. Rev. Algol. (Nouv. Sér.) 5: 247-259

Fenchel, T., Perry, T., Thane, A. (1977). Anaerobiosis and symbiosis with bacteria in free-living ciliates. J. Protozool. 24: $154-163$

Goldman, J. C., McCarthy, J. J., Peavey, D. G. (1979). Growth rate influence on the chemical composition of phytoplankton in oceanic waters. Nature, Lond. 279: 210-215

Gooday, G. W. (1970). A physiological comparison of the symbiotic alga Platymonas convolutae and its free-living relatives. J. mar. biol. Ass. U. K. 50: 199-208

Guillard, R. R. L. (1963). Organic sources of nitrogen for marine centric diatoms. In: Oppenheimer, C. H. (ed.) Symposium on marine microbiology. C. C. Thomas, Springfield, pp. 93-104

Hartwig, E., Parker, J. G. (1977). On the systematics and ecology of interstitial ciliates of sandy beaches in North Yorkshire. J. mar. biol. Ass. U. K. 57: 735-760

Kapp, R., Stevens, S. E., Jr., Fox, J. L. (1975). A survey of available nitrogen sources for growth of the blue-green alga Agmenellum quadruplicatum. Arch. Microbiol. 104: 135-138

Mahoney, J. B., McLaughlin, J. J. A. (1977). The association of phytoflagellate blooms in lower New York Bay with hypertrophication. J. exp. mar. Biol. Ecol. 28: 53-65

McCarthy, J. J., Goldman, J. C. (1979). Nitrogenous nutrition of marine phytoplankton in nutrient-depleted waters. Science, N. Y. 203: 670-672

Parker, J. G. (1978). Further observations on cultures of the marine ciliated protozoan Uronema marinum Dujardin. J. exp. mar. Biol. Ecol. 35: 265-271

Pfleiderer, W. (1963). The solubility of heterocyclic compounds. In: Katritzky, A. R. (ed.) Physical methods in heterocyclic chemistry, Vol. 1. Academic Press, New York, pp. $177-188$

Porter, K. G., Pace, M. L., Battey, J. F. (1979). Ciliate protozoans as links in freshwater planktonic food chains. Nature, Lond. 277: 563-565

Radzikowski, S., Golembiewska, M. (1977) Chilodonella steini - the ciliate specifically feeding on diatoms routine culture method. J. Protozool. 24 (Abst. Suppl.): $27 \mathrm{~A}$

Repak, A. J., Provasoli, L., Pintner, I. J. (1979). Preliminary nutritional studies of Fabrea. J. Protozool. 26 (Abst. Suppl.): $26 \mathrm{~A}$

Soldo, A. T., Godoy, G. A., Larin, F. (1978). Purine-excretory nature of refractile bodies in the marine ciliate Parauronema acutum. J. Protozool. 25: 416-418

Turner, M. F. (1970). A note on the nutrition of Rhodella. Br. Phycol. J. 5: 15-18 
Turner, J. T., Ferrante, J. G. (1979). Zooplankton fecal pellets in aquatic ecosystems. BioScience 29: 670-677

Valiela, I., Teal, J. M. (1979). The nitrogen budget of a salt marsh ecosystem. Nature, Lond. 280: 652-656

Van Baalen, C., Marler, J. E. (1963). Characteristics of marine blue-green algae with uric acid as nitrogen source. J. Gen. Microbiol. 32: 457-463

Vogels, G. D., Van der Drift, C. (1976). Degradation of purines and pyrimidines by microorganisms. Bact. Rev. 40 : $403-468$

This paper was submitted to the editor; it was accepted for printing on January $14,1980$. 